\title{
TITLE:
}

\section{Curcumin inhibits glucose production in isolated mice hepatocytes(Abstract_要旨)}

\author{
$\operatorname{AUTHOR}(S)$ : \\ Fujiwara, Hideya
}

\section{CITATION:}

Fujiwara, Hideya. Curcumin inhibits glucose production in isolated mice hepatocytes. 京 都大学, 2008, 博士 (医学)

\section{ISSUE DATE:}

2008-07-23

URL:

http://hdl.handle.net/2433/124224

RIGHT: 


\begin{tabular}{|l|l|c|l|}
\hline 京都大学 & 博士 (医学) & 氏 名 & 藤原 秀哉 \\
\hline 論文題目目 & $\begin{array}{l}\text { Curcumin inhibits glucose production in isolated mice hepatocytes (マウス } \\
\text { 単離肝細胞においてクルクミンはブドウ糖産生を抑制する) }\end{array}$ \\
\hline
\end{tabular}

\section{(論文内容の要旨)}

クルクミンは、カレー粉に含まれるターメリックの一成分であり、抗炎症作用、抗酸化作用、抗癌作用を 有寸ることが知られている。さらに糖尿病ラットにおいては、血糖改善作用を有寸ることが報告されてい る。2型糖尿病の病態においては、高血糖の原因として肝糖産生克進がしばしば認められるが、クルクミ ンの肝臟におけるブドウ糖代謝に対する影響については未だ報告がない。そこで本研究では、肝糖産 生に対するクルクミンの影響について明らかにすることを目的とした。方法として、健常の絶食マウスから 単離した肝細胞を用いて培養液中の pyruvate や dihydroxyacetone phosphate を基質にした糖新生に対 する影響を検䛉たところ、2 $2 \mu \mathrm{M}$ クルクミンの 2 時間暴露は刘照群し比較して各々 $45 \%$ 、35\%糖新生を 抑制した。そしてクルクミンは $1 \mu \mathrm{M}$ から $25 \mu \mathrm{M}$ の範囲で濃度依存性に pyruvateからの糖新生を抑制し た。高濃度のインスリン $(10 \mathrm{nM})$ 存在下に $25 \mu \mathrm{M}$ のクルクミンを加えると、糖新生はインスリン単独の暴露 時よりも更に 45\%抑制された。以上の結果から、クルクミンはインスリンシグナリングとは独立した細胞内 情報伝達経路を介して糖新生を抑制すると考古れた。

さらに肝臟グリコーゲン分解から生じる糖産生に対するクルクミンの影響を検討した。自由摂食マウス から単離した肝細胞において $25 \mu \mathrm{M}$ クルクミンの 2 時間暴露は、対照群と比較してグリコーゲン分解から 生じる糖産生を $20 \%$ 抑制した。そしてクルクシンは $1 \mu \mathrm{M} か ら 25 \mu \mathrm{M}$ の範囲て濃度依存性にグリコーゲン

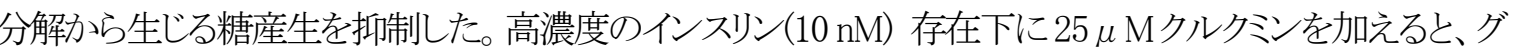
リコーゲン分解はインスリン単独の暴露時よりも更に $20 \%$ 抑制された。以上の結果から、クルクシンはインス リンシグナリングとは独立した細胞内情報伝達経路を介してグリコーゲン分解を抑制すると考えられた。

次にクルクミンが肝糖新生を抑制する双ニズムを明らかにするために、糖新生を制御する3つの律 速段階酵素である glucose-6-phosphatase（G6Pase），fructose-1,6-bisphosphatase（FBPase), phosphoenolpyruvate carboxykinase (PEPCK)の活性に及ぼすクルクミン $(25 \mu \mathrm{M})$ の影響について検討 た。2時間のクルクミン暴露は FBPase 活性に影響しなかったが、G6Pase ならびに PEPCK の活性を 30\% 低下させた。肝臟における AMP kinase の活性化は、インスリンとは独立した作用機序を通じて G6Pase と PEPCK の両遺伝子発現を抑制し糖新生を抑制することが知られている。そこでクルクミン $(25 \mu \mathrm{M})$ の AMP kinase 活性への影響を検討したところ、2時間のクルクミン暴露は、AMP kinase $\alpha$ 鎖の 172番目のア ミ酸残基であるスレオニンのリン酸化を促進し活性を増加させた。従って、クルクミンは朋藏において AMP kinase を活性化し、G6Pase 活性と PEPCK 活性を抑制することにより、肝桾新生を抑制することが示 された。

以上の結果から、クルクミンは、肝糖新生ならびにグリコーゲン分解を抑制することにより肝糖産生を抑制 し、抗糖尿病作用を発揮する可能性が示唆された。
（論文審査の結果の要旨 $)$

クルクミンはカレー粉に含まれる抗酸化物質であり、糖尿病ラットにおいては血糖改善作用を有する ことが報告されているが、そのメカニズムについては不明な点が多い。

申請者は、健常の絶食マウスならびに自由摂食マウスから単離した肝細胞を用いて、糖新生基質から 生じる糖新生ならびにグリコーゲン分解から生じる糖産生に及ぼすクルクミンの影響について検討し た。クルクミンは濃度依存性に、糖新生ならびて糖産生を抑制した。またインスリンとクルクミンの同 時曝露は、糖新生ならびに糖産生を相加的に抑制した。したがって、クルクミンはインスリンシグナル とは独立した細胞内情報伝達経路を介して、肝細胞における糖新生基質から生じる糖新生ならびにグリ コーゲン分解から生じる糖産生を抑制することが示された。

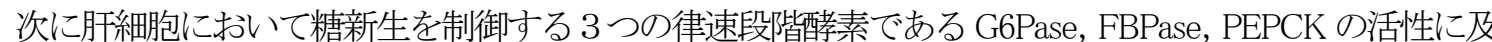
ぼすクルクミンの影響について検討した。その結果、FBPase 活性には影響を及ぼさなかったが、G6Pase ならびに PEPCK の活性を低下させた。さらにクルクミンは G6Pase と PEPCK の両遺伝子発現を抑制す ることが知られている AMP kinase 活性を増加させた。

以上の結果は、クルクミンが朋臟において AMP kinase を活性化し、G6Pase 活性と PEPCK 活性を抑制 寸ることにより糖新生を抑制し、抗糖尿病作用を発揮する可能性を示唆している。以上の研究は、食物 成分に由来寸る抗酸化物質のクルクミンが朋臟における糖代謝を改善寸ることを明らかにし、糖尿病の 病態の解明ならびに新たな治療法の開発に寄与寸るところが大きい。

したがって、本論文は博士 (医学) の学位論文として価值のあるものと認める。なお、本学位授与申 請者は、平成 20 年 5 月 12 日実施の詥文内容とそれに関連した試問を受け、合格と認められたものでめ ろ。 